\title{
MEGGYMAG KIVONAT - EGY ÚJ TERMÉK A FUNKCIONÁLIS ÉLELMISZEREK PIACÁN?
}

\author{
- no \\ SOUR CHERRY SEED EXTRACT - AN EMERGING FUNCTIONAL FOOD

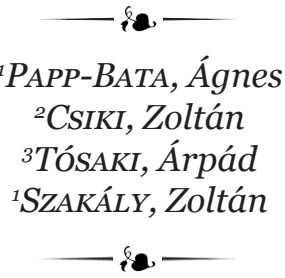 \\ Debreceni Egyetem, Gazdaságtudományi Kar, Marketing és Kereskedelem Intézet \\ (University of Debrecen, Faculty of Economics, Institute of Marketing and Commerce) \\ H-4032 Debrecen, Böszörményi út 138. \\ e-mail: dr.pappagi@gmail.com \\ ${ }^{2}$ Debreceni Egyetem, Általános Orvostudományi Kar, Belgyógyászati Intézet, Klinikai Immunológiai Tanszék \\ (Department of Clinical Immunology, Institute of Medicine, Faculty of Medicine, University of Debrecen) \\ H-4032 Debrecen, Móricz Zsigmond út 22. \\ ${ }^{3}$ Debreceni Egyetem, Gyógyszerésztudományi Kar, Gyógyszerhatástani Tanszék \\ (Department of Pharmacology, Faculty of Pharmacy, University of Debrecen) \\ H-4012 Debrecen, Nagyerdei krt. 98.
}

a Advanced analytical techniques have recently revealed powerful health-promoting properties in components of some plants, which had remained obscure until present days because they were not typically consumed as food by humans. A particularly fascinating example is the seed kernel of sour cherry (Prunus cerasus). Chemical analysis of the seed kernel revealed that the solid flavonoid-rich fraction, comprising approximately $64-68 \%$ of the kernel, contains several healthenhancing polyphenolic compunds including catechins, stillbenes, anthocyanidins and resveratrol. The remaining $32-36 \%$ is an oil fraction rich in tocopherols and related compounds, including tocotrienols, oleic acid and triglycerides. Previous studies demonstrated that oral administration of sour cherry seed extract to animals strongly stabilizes healthy tissue homeostasis and suppresses ischemia-reperfusion injury by augmenting expression of heme oxygenase-1, a major endogenous cytoprotective enzyme. The sour cherry fruit is a major export of several nations, including Hungary, however the seed is currently considered an agricultural by-product and discarded. The better understanding of health protective effects of the seed extract would open new avenues for the Hungarian agriculture and food industry in the future.

\section{BEVEZETÉS - INTRODUCTION}

A szív- és érrendszeri megbetegedések és azok szövődményei, úgy mint a szívinfarktus, stroke, veseelégtelenség és perifériás érbetegségek világszerte vezetik a morbiditási és mortalitási statisztikákat, az összes halálozás több mint harmadáért tehetők felelőssé. A kardiovaszkuláris kórképek legfontosabb hajlamosító tényezői között tartjuk számon a nem megfelelő táplálkozást, az elhízást, a magas vérnyomást, a cukorbetegséget, a diszlipidémiát, a dohányzást és a mozgásszegény életmódot [1]. Habár a felsorolt rizikófaktorok jellemzően az úgynevezett civilizációs betegségek kategóriájába tartoznak, az elmúlt években megfigyelhető tendenciák alapján a fejlett országok mellett immár a fejlődő országok többségében is jelentősen emelkedik az előfordulásuk. A WHO előrejelzése alapján a kardiovaszkuláris morbiditás és mortalitás jelentős növekedésére számíthatunk az elkövetkezó évtizedekben [2], mely a népegészségügyi jelentőségén túlmenően súlyos egyéni, társadalmi és gazdasági 
terhekkel is jár. Mindezek következtében a már kifejlődött kórállapotok kezelésén és szövődményeinek ellátásán túlmenően a betegségmegelőzés szerepe napjainkra stratégiai fontosságúvá vált.

Az elmúlt évtizedek klinikai kutatásai bebizonyították, hogy a táplálkozásnak, mint környezeti tényezőnek (a genetikai hajlamosító faktorok mellett) kiemelt szerepe van a szív- és érrendszeri betegségek, a cukorbetegség, az elhízás, a magas vérnyomás és a rosszindulatú daganatok kialakulásában. Mindezek komoly kihívások és egyszersmind ígéretes piaci lehetőségek elé állítják az élelmiszeripart: olyan új, úgynevezett funkcionális élelmiszereket kell kifejlesztenie, melyek az alapvető táplálkozási hatáson túlmenően egészségvédő funkcióval is rendelkeznek, ami által hozzájárulnak a betegségek kockázatának csökkentéséhez. A funkcionális élelmiszerek értékesítésének üteme a világszerte tapasztalható trendeknek megfelelően Magyarországon is meghaladja a konvencionális élelmiszerek értékesítésének átlagos növekedési ütemét, melynek hátterében az egyre terjedő egészségtudatos táplálkozás, a fogyasztók betegségtől való félelme, a gyógykezelések egyre magasabb költsége és a funkcionális élelmiszerekkel kapcsolatos attitűdök pozitív irányú változása áll [3].

\section{A MEGGYMAG, MINT ÉLELMISZER- ÉS GYÓGYSZERIPARI ALAPANYAG - SOUR CHERry SEEd AS FoOd AND Pharmaceutical RaW Material}

A funkcionális élelmiszerek piachódításával párhuzamosan az elmúlt évek kutatásainak köszönhetően előtérbe kerültek olyan természetes eredetű növényi termékek is, melyeket korábban nem tartottak kifejezetten emberi fogyasztásra alkalmasnak. Ennek egyik legígéretesebb példája áll írásunk fókuszában: a meggy (Prunus cerasus) magja. Ez a gyümölcs hazánk egyik fó exportterméke, azonban magját az élelmiszeripar jelenleg hasznosíthatatlan mezőgazdasági mellékterméknek tartja. A nemzetközi szakirodalomban azonban egyre több beszámoló jelenik meg a meggymag-kivonat előnyös egészségügyi hatásait illetően, sőt már évekkel ezelőtt felmerült a potenciális szerepe a funkcionális élelmiszerek fejlesztésében [4].

$\mathrm{Az}$ előállítási eljárás során a meggymagok csonthéját eltávolítják, a belső részükből pedig őrlést követően kivonatot készítenek. A kivonat vízmentesítését követően a termék olajos és szilárd fázisra különíthető el. Az olajos fázis triglicerideket, olajsavat, alfa-tokoferolt, toko-trienolokat és egyéb tokoferol-szerü anyagokat tartalmaz. A kivonat 64-68\%-át képező szilárd fázisban számos biológiai aktív hatású vegyület van, melynek 2-4\%-a cianid, 1-4\%-a flavonoid, 1-3\%-a polifenol, 1-3\%-a növényi sav, $1-2 \%$-a pro- és antocianidin, $1 \%$-a transz-reszveratrol, $1 \%$-a stilbene és $1 \%$-a katekin [5].

\section{A MEgGYMag KivONAT Élettani hATÁSAI - Biological EFFECTS OF Sour Cherry SEEd EXTRACT}

Az elmúlt évek vizsgálatai igazolták a meggymag kivonat szöveti homeosztázisra gyakorolt stabilizáló hatásait. A készítmény fogyasztása mellett a szív- és érrendszeri betegségek patomechanizmusában kulcsszerepet játszó iszkémiás és reperfúziós folyamatok következtében kialakuló szövet- és szervkárosodás mértéke a vizsgált állatmodellekben jelentősen csökkent. Biológiai hatékonyságának hátterében az eddigi kutatások alapján erős antioxidáns és citoprotektív hatása áll [6]. A meggymag kivonat fogyasztása stimulálja az indukálható hem oxigenáz-1 (HO-1), egy endogén sejtvédő enzim expresszióját, mely által fokozza az iszkémiás, illetve reperfúziós stressznek kitett szövetek ellenálló képességét [7; 8]. A HO-1 aktivitása során továbbá szénmonoxid képződik, mely az érfal tónus és vérlemezke funkció szabályozásának fontos eleme. Genetikai módosítás során kiváltott fokozott HO-1 expresszió igazoltan idegsejtvédő hatásokkal rendelkezik agyi érbetegségekben [9]. Laboratóriumi vizsgálatok során az előzetesen meggymag kivonattal etetett egészséges állatok retináján, illetve izolált szívizom preparátumán kiváltott iszkémiás-reperfúziós károsodások kapcsán is bizonyították a készítmény dózisfüggő protektív hatását, bármilyen káros mellékhatás észlelése nélkül $[8 ; 10]$. Egy nemrég publikált tanulmány hiperkoleszterinémiás állatmodell vizsgálata által erősítette meg a meggymag kivonat eróteljes kardioprotektív hatásait. A készítménnyel történő táplálás szignifikáns mértékben növelte a szívizom HO-1 expresszióját, csökkentette a szérum koleszterin szintet és az ateroszklerózis mértékét, továbbá javította a szívfunkciót és a szívkoszorúerek átjárhatóságát [11]. A kapcsolódó klinikai és toxikológiai vizsgálatok alapján a meggymag kivonat emberi fogyasztása mind prevenciós, mind terápiás célzattal a vizsgált beviteli értékek mellett nem jár máj- vagy vesefunkció romlással, illetve egyéb egészségkárosító mellékhatásokkal [12]. A meggymag kivonat az eddigi kutatási eredmények alapján a közeljövőben hatékonyan alkalmazható termék, 
illetve termék-összetevő lehet nem csak a szív- és érrendszeri betegségek prevenciójában, de azok gyógyszeres terápiájában is.

\section{MEGGYTERMESZTÉS HAZÁNKBAN - EGY ÚJ LEHETÓSÉG \\ KAPUJÁBAN? - SOUR CHERRY \\ Production In HUNGARY - OPENING A DOOR TO NEW OPPORTUNITIES}

A világ 1,1-1,3 millió tonna körüli éves meggytermelésének 1/3-a (300-400 ezer tonna) az Európai Unióból származik. Az EU-ban előállított termés 70-80\%-át három ország állítja elő: Lengyelország (150-200 ezer t), Magyarország (40-70 ezer t) és Németország (30-40 ezer t), tehát hazánk az EU második legnagyobb meggytermelőjének tekinthető [13]. Magyarország a legfrissebb statisztikai adatok szerint közel 15 ezer hektár meggyültetvénnyel rendelkezik, az éves termés pedig 50-60 ezer tonna körül mozog, mely alapján az országos átlagtermelés meglehetően alacsony - 3-4 tonna/ hektár - értéket mutat. A külkereskedelmi adatokat tekintve 16-22 ezer tonna körül mozog a kivitel mennyisége (1. táblázat). Az össztermelés és kivitel volumene ellenére a meggytermesztés mégsem tartozik az elmúlt években a hazai kertészet sikerágai közé. A meggypiac problémái alapvetően nem az állandó jellegü, tartós túltermeléshez kapcsolódnak, hanem sokkal inkább a piac évek közötti, de akár szezonon belüli rendkívüli mértékủ kiszámíthatatlanságához és a hazai feldolgozóipari kereslet beszűküléséhez. Mindezek következtében több ezer hektárnyi gondozatlan, illetve rossz terméshozamú régi telepítésű ültetvénnyel és a termelői réteg leépülésével kell számolnunk, mely különösen az Észak-Alföld régióban okozhat súlyos gazdasági és egzisztenciális gondokat. A gazdaságos meggytermelés fenntartásához elengedhetetlen a hozamok növelése az elöregedett ültetvények újratelepítésével, a költségek racionalizálása technológiai fejlesztésekkel (gépi betakarítás), de legfőképpen a hazai feldolgozóipar fejlesztése, mely utóbbi a megtermelt meggy stabil felvevőjeként szolgál.

TABLE 1

1. TÁBLÁZAT

A meggy termesztésének és felhasználásának alakulása hazánkban (Sour Cherry Production and Sales in Hungary in the Past Years)

\begin{tabular}{lccc}
\hline & $\mathbf{2 0 1 0}$ & $\mathbf{2 0 1 1}$ & $\mathbf{2 0 1 2}$ \\
\hline Gyümölcsösterület (hektár) (Producing area in hectares) & 14932 & 14486 & 14551 \\
\hline Betakarított termés (tonna) (Harvested fruit in tonnes) & 51870 & 61735 & 53425 \\
\hline Értékesítés összesen (tonna) (Total sales in tonnes) & 49217 & 57105 & 49251 \\
\hline Kivitel (tonna) (Exports in tonnes) & 19636 & 22160 & 15716 \\
\hline
\end{tabular}

Forrás (Source): Központi Statisztikai Hivatal [14]

\section{KöVETKEZTETÉSEK - CONCLUSIONS}

Összességében Magyarország a komparatív mezőgazdasági és élelmiszeripari előnyei révén hatékony szerepet tölthetne be a funkcionális élelmiszerek kifejlesztésében, termelésében, hazai és külföldi forgalmazásában. A valódi piacképes fejlesztések, így a meggymag kivonat új generációs hungarikumként való bevezetése hazánk számára követő helyett, piacot alakító pozíciót biztosíthatna. 


\section{IRODALOMJEGYZÉK - REFERENCES}

[1] Wilson, P. W. - D'Agostino, R. B. - Levy, D. - Belanger, A. M. - Silbershatz, H. Kannel, W. B.: Prediction of Coronary Heart Disease Using Risk Factor Categories. In: Circulation. 1998. 97 (18) 1837-1847.

[2] Mendis, S. - Puska, P. - Norrving, B.: Global Atlas on Cardiovascular Disease Prevention and Control. World Health Organization, Geneva, 2011. URL: http://whqlibdoc.who.int/ publications/2011/9789241564373_eng.pdf (letöltés ideje: 2014. március 10.)

[3] Szakály Z.: Egészségmagatartás és funkcionális élelmiszerek: hogyan vélekednek a hazai fogyasztók? In: Élelmiszer, Táplálkozás és Marketing. 2009. 6 (1-2) 9-18.

[4] Blando, F. - Gerardi, C. - Nicoletti, I.: Sour Cherry (Prunus cerasus L) Anthocyanins as Ingredients for Functional Foods. In: $\mathrm{J}$ Biomed Biotechnol. 2004. (5) 253-258.

[5] Bak, I. - Lekli, I. - Juhasz, B. - Varga, E. - Varga, B. - Gesztelyi, R. - Szendrei, L. - Tosaki, A.: Isolation and Analysis of Bioactive Constituents of Sour Cherry (Prunus cerasus) Seed Kernel: an Emerging Functional Food. In: J Med Food. 2010. 13 (4) 905-910.

[6] Piccolella, S. - Fiorentino, A. - Pacifico, S. - D'Abrosca, B. - Uzzo, P. - Monaco, P.: Antioxidant Properties of Sour Cherries (Prunus cerasus L): Role of Colorless Phytochemicals from the Methanolic Extract of Ripe Fruits. In: J Agric Food Chem. 2008. 56 (6) 1928-1935.

[7] Mahmoud, F. F. - Al-Awadhi, R. Haines, D. D. - Dashti, A. - Dashti, H. - Al-Ozairi, E. - Bak, I. - Tosaki, A.: Sour Cherry Seed Kernel Extract Increases Heme Oxygenase-1 Expression and Decreases Representation of $\mathrm{CD} 3+\mathrm{TNF}-a$ lpha+ and CD3+IL-8+ Subpopulations n Peripheral Blood Leukocyte Culture from Type 2 Diabetes Patients. In: Phytother Res. 2013. 27 (5) 767774.
[8] Szabo, M. E. - Gallyas, E. - Bak, I. Rakotovao, A. - Boucher, F. - de Leiris, J. - Nagy, N. - Varga, E. - Tosaki, A.: Heme Oxygenase-1-related Carbon Monoxide and Flavonoids in Ischemic/Reperfused Rat Retina. In: Invest Ophthalmol Vis Sci. 2004. 45 (10) 3727-3732.

[9] Panahian, N. - Yoshiura, M. - Maines, M. D.: Overexpression of Heme Oxygenase-1 is Neuroprotective in a Model of Permanent Middle Cerebral Artery Occlusion in Transgenic Mice. In: J Neurochem. 1999. 72 (3) $1187-1203$.

[10]Bak, I. - Lekli, I. - Juhasz, B. - Nagy, N. - Varga, E. - Varadi, J. - Gesztelyi, R. - Szabo, G. - Szendrei, L. - Bacskay, I. - Vecsernyes, M. - Antal, M. - Fesus, L. - Boucher, F. - de Leiris, J. - Tosaki, A.: Cardioprotective Mechanisms of Prunus Cerasus (Sour Cherry) Seed Extract Against Ischemia-eperfusion-induced Damage in Isolated Rat Hearts. In: Am J Physiol Heart Circ Physiol. 2006. 291 (3) H1329-H1336.

[11] Juhasz, B. - Kertesz, A. - Balla, J. - Balla, G. - Szabo, Z. - Bombicz, M. - Priksz, D. - Gesztelyi, R. - Varga, B. - Haines, D. D. - Tosaki, A.: Cardioprotective Effects of Sour Cherry Seed Extract (SCSE) on the Hypercholesterolemic Rabbit Heart. In: Curr Pharm Des. 2013. 19 (39) 6896-6905.

[12] Bak, I. - Czompa, A. - Csepanyi, E. Juhasz, B. - Kalantari, H. - Najm, K. - Aghel, N. - Varga, B. - Haines, D. D. - Tosaki, A.: Evaluation of Systemic and Dermal Toxicity and Dermal Photoprotection by Sour Cherry Kernels. In: Phytother Res. 2011. 25 (11) 1714-1720.

[13] Apáti F.: A meggytermesztés jelene és kilátásai a gazdaságosság tükrében (1.) A magyar meggytermesztés költség- és jövedelemviszonyai. In: Agrofórum. 2009. 20 (28) 34-38.

[14] www.ksh.hu: URL: www.ksh.hu/docs/ hun/xstadat/xstadat_eves/i_omnoo6b.html (letöltés ideje: 2014. március 12.) 